\title{
Skryté kurikulum, žité příběhy. Narativy studentů učitelství o škole ${ }^{1}$
}

\author{
Kateřina Lojdová \\ Masarykova univerzita, Pedagogická fakulta, Katedra pedagogiky \\ Redakci zasláno 11. 5. 2015 / upravená verze obdržena 27. 7. 2015 / \\ k uveřejnění přijato 6. 8. 2015
}

\begin{abstract}
Abstrakt: Empirická studie je věnována skrytému kurikulu v př́bězích o zkušenostech studentů učitelství se školou. Výsledkem narativní analýzy 88 studentských vyprávění je identifikace dvou typů skrytého kurikula. Kritériem pro typologii je to, zda se skryté kurikulum utváří mezi aktéry na různých sociálních pozicích ve škole, mezi kterými je hierarchický vztah, nebo mezi aktéry na stejných sociálních pozicích ve škole, mezi kterými je vztah nehierarchický. První typ je označen jako vertikální skryté kurikulum a utváří se mezi aktéry na odlišných sociálních pozicích ve škole, tedy nejčastěji mezi učiteli a žáky. Vertikální skryté kurikulum odhaluje konflikty mezi žáky a školou, které se objevují zejména v hodnotové rovině, dále pak rituály, kterými škola hodnoty prosazuje, s tím související podobu moci školy a rezistence žákủ vůči této moci. V neposlední řadě je součástí vertikálního skrytého kurikula také bezmoc školy, a to v situacích, kdy mají žáci ve škole mocenskou převahu. Druhý typ skrytého kurikula je označen jako horizontální skryté kurikulum a vztahuje se $\mathrm{k}$ aktérům na stejných sociálních pozicích, tedy k žákovskému kolektivu. Opět se týká zejména hodnot, které se žáci ve škole učí, tentokrát však ve tř́ídním kolektivu. Dochází zde $\mathrm{k}$ vzájemnému vyjednávání identit žáků. $V$ neposlední řadě je zachyceno, jak do žákovských vztahů zasahují učitelé, kteří tak proměňují obsah horizontálního skrytého kurikula. Závěrem je diskutován význam zkušeností ze skrytého kurikula v průběhu povinné školní docházky pro budoucí učitele.
\end{abstract}

Klíčová slova: biografie, narativní analýza, skryté kurikulum, studenti učitelství

„Je zvláštní, jaké zážitky a zkušenosti nám dává škola, instituce, která vychovává budoucí generace," napsala jedna ze studentek pedagogické fakulty v reflexi svého prŕíběhu ze základní školy. Reagovala tak na to, že mnohé školní zkušenosti, které se žáků osobně dotýkají, nejsou spojeny jen s formálním kurikulem. V současné pedagogické vědě se uvažuje jak o formálním, tak

1 Tento př́spěvek vznikl s podporou projektu GAČR GA13-24456S Moc ve školních trídách studentů učitelství řešeného na Katedře pedagogiky Pedagogické fakulty Masarykovy univerzity. Autorka děkuje za poskytnutou podporu.

DOI: 10.5817/PedOr2015-5-649 
i o skrytém kurikulu, nebot' obojí utváří edukační realitu ve škole. Koncept skrytého kurikula je nyní dokonce na výsluní pedagogické vědy. Odpovídají tomu nejen tisíce článků v uznávaných periodikách, ale i samostatné konference a výzkumná centra zaměřená na tento fenomén (Kaščák, 2011, s. 30). Na druhou stranu zejména v česko-slovenské pedagogické vědě skrytému kurikulu nebyla věnována taková pozornost. Skryté kurikulum uniká pečlivějšímu pohledu a hlubším úvahám (Jirásek, 2009, s. 53) a ve většině publikací se zpravidla popisuje jen povšechně, bez citování autoritativních pramenů a bez důkladného empirického výzkumu (Švaříček, 2008, s. 170). Bomba (2013, s. 28) uvádí, že většinou skončíme při konstatovaní, že skryté kurikulum existuje a že si ho žáci ve škole osvojují (srov. Kaščák \& Filagová, 2007). Cílem této studie je otevř́t diskusi nad oblastmi skrytého kurikula na základě empirických dat.

\section{$1 \quad$ Skryté kurikulum}

Teoretické a metodologické uchopení konceptu skrytého kurikula je poměrně obtížné. Hranici mezi formálním a skrytým kurikulem nelze jednoznačně stanovit (Bomba, 2013, s. 28), nebot' vztah formálního a skrytého kurikula je velmi proměnlivý (Jirásek, 2009, s. 54). V edukační realitě se obojí překrývá. Ve škole je v podstatě jen jedno kurikulum, které má tři aspekty (Janík et al., 2010, s. 13): (1) co je plánováno (zamýšlené kurikulum), (2) co je vyučováno (realizované kurikulum), (3) jakou zkušenost si žáci odnesou (dosažené kurikulum). Působení skrytého kurikula se dle autorů patrně nejvýrazněji uplatňuje v realizační formě. Kurikulum tedy souběžně obsahuje formální i skryté aspekty. Stejně tak proces učení ve škole nelze charakterizovat jen skrze formální vzdělávání, ale také skrze informální učení, nebot' tyto procesy se také překrývají. I v důsledku této rozmanitosti edukační reality není skryté kurikulum v pedagogické vědě uchopeno jednotně.

Termín skryté kurikulum byl poprvé použit P. Jacksonem v roce 1968 k zachycení disproporce mezi tím, co je ve školách vyučováno, a tím, co se žáci skutečně učí (Cotton, Winter, \& Bailey, 2013, s. 192). Analytické přístupy ke skrytému kurikulu pak byly často spojeny s kritickými směry, které odhalují, jak vzdělání reprodukuje nerovnosti ve společnosti. ${ }^{2}$ Hemmingsová

Willisova (1977) klasická studie zachycuje skryté kurikulum ve smyslu funkce školy v socializaci chlapců $\mathrm{z}$ dělnických rodin $\mathrm{k}$ tomu, aby se $\mathrm{z}$ nich stali poslušní dělníci. Ke kritickému pojetí skytého kurikula dále přispěly zejména dvě McLarenovy publikace: Schooling as ritual performance (1986) a Life in schools (1998). McLaren pojímá skryté kurikulum jako tacitní 
(2000) shrnuje, že výzkumníci skrze skryté kurikulum zejména popisovali, jak se reprodukují sociální, rasové a genderové rozdíly.

Tyto studie mohou vzbudit mylný dojem, že skryté kurikulum je prostředkem indoktrinace žáků a je proto jevem čistě negativním. Tak tomu však není, skrze skryté kurikulum se žáci učí mnoho pozitivního. Ve vztahu ke vzdělávání v Izraeli uvádí Dar (1995), že skryté kurikulum v tomto kulturním kontextu podporuje prosociální orientaci a pocit sounáležitosti. Valenta (2009, s. 210) považuje za součást skrytého kurikula sociální dovednosti, které se rozvíjí skrze sociální klima školy, učitelské jednání a vzájemné vztahy, a to průběžně, bez přímého zásahu učitele. Dále Lovat, Toomey a Clement (2010, s. 305) poznamenávají, že skrytým kurikulem se učíme např́klad smyslu pro humor. Skryté kurikulum samo o sobě proto chápeme jako hodnotově neutrální pojem.

Skryté kurikulum spolu s Hargreavesem (1982) vymezujeme jako vše, co se žáci ve škole učí, a není to záměrně komunikováno učiteli a školním systémem. Skryté kurikulum můžeme v obecné rovině chápat jako neoficiální pravidla, rutiny a struktury školy, ve kterých se žáci učí vzorce chování, hodnoty, názory a postoje (Lovat et al., 2010, s. 304). Konkrétněji lze aspekty skrytého kurikula nalézt ve školních normách, ceremoniálech, rituálech, dokumentech, způsobech hodnocení studentů, o přestávkách, na chodbách, na obědě, ve volnočasových aktivitách, skrze diskurs ve školní třídě, atmosféru ve třídě, kázeňský systém, prostorové uspořádání školní třídy, v učebnicích, a dokonce i ve formálním kurikulu (Çobanoğlu, 2014). Formální kurikulum může fungovat také jako skryté, což dobře ilustrují např́klad výzkumy genderu ve škole. Jarkovská (2013) analyzovala mimo jiné hodiny sexuální výchovy, jejichž hlavní náplň sestávala z témat spojených s reprodukcí (menstruace, početí, porod). Ženy a jejich orgány v těchto hodinách nevystupovaly v aktivní roli na rozdíl od mužů a jejich orgánů. Ženské tělo bylo jen pasivní kulisou pro mužskou akci. Ve vztahu k formálnímu kurikulu je skryté kurikulum

způsoby, kterými se žáci učí vědění a vzorce chování, které jsou v souladu s dominantními ideologiemi a kulturními praktikami. Tacitní jsou tyto způsoby proto, že nejsou učiteli plánované a uvědomované. Nacházejí se za oponou plánovaného kurikula, oficiálního předmětu a vzdělávacích materiálů. $V$ tomto smyslu můžeme chápat skryté kurikulum jako nezáměrné výstupy vzdělávání (McLaren, 1998). Také Aronowitz a Giroux (2003) přistupují ke skrytému kurikulu jako k prostředku, skrze který dominantní kapitalistická ideologie utváŕí školní zkušenost a přispívá k reprodukci pracovních sil mnohdy „za zády“ žáků a učitelů. Kritičtí pedagogové Kincheloe a Steinberg (1997) dodávají, že hodnotová reprodukce ve škole spíše podporuje dominantní status quo než potřeby žáků. 
často spojováno s fenomény, které vyplývají z nerovností ve společnosti, jež škola reprodukuje nebo vytvárín.

Je tedy zřejmé, že skryté kurikulum představuje neodmyslitelnou součást školní socialiazce. Skryté kurikulum a proces socializace ve škole jsou úzce provázané. Maňák (2007, s. 45) spojuje skryté kurikulum s působením prostředí, tedy s doménou socialiazce. Bulle (2008, s. 104) nahlíží na skryté kurikulum jako na proces socializace skrze vzdělávací systém, ve kterém jsou žákům zprostředkovány sociální normy a hodnoty dané společnosti. Přesto tyto pojmy nezaměňujeme a školní socializaci považujeme za širší proces, jehož významnou součástí je právě skryté kurikulum a informální učení ve škole. ${ }^{3}$

Některé přístupy ke zkoumání skrytého kurikula jsme již naznačili, nyní je shrneme. Je obtížné určit nejvhodnější metodologický přístup ke zkoumání skrytého kurikula. Literatura však vypovídá o tom, že vhodnými př́stupy jsou zde přístupy kvalitativní, které jsou více otevřené neznámému a dokáží rozlišovat jemné nuance sociální reality (srov. Cotton et al., 2013). Dominantní místo má zřejmě zúčastněné pozorování a etnografický výzkum. Zmíněné výzkumy Jacksona a Willise byly charakteristické dlouhodobou interakcí výzkumníka se školním prostředím. Součástí etnografických výzkumů jsou také rozhovory. Využívanými metodami byly nestrukturované rozhovory, at' už jako součást etnografických výzkumů, nebo samostatně. Ke zkoumání skrytého kurikula byla využita i videoanalýza, jak shrnuje Kaščák (2011). Nalezneme také výzkumy založené na focus group se studenty (Ozolins, Hall, \& Peterson, 2008) a ojedinělé nejsou ani biografické a narativní přístupy. Ahweeová a kol. (2004) využili př́běhy vysokoškolských studentů se skrytým kurikulem. Bohužel se nedozvídáme, jaké bylo přesné zadání pro psaní narativů ani jak proběhla jejich analýza.

Protože je skryté kurikulum spojováno s informálním učením ve škole, v literatuře se také objevuje pojem informální kurikulum, který se vztahuje k předávání informací skrze interakce mezi aktéry ve škole (Fryer-Edwards, 2002). Pro skryté kurikulum není významné jen to, co se ve škole vyskytuje, ale také to, co $\mathrm{v}$ ní absentuje. $\mathrm{K}$ tématům vyloučeným $\mathrm{z}$ kurikula se vztahuje termín nulové kurikulum. Jednoduše řečeno, vyučujeme i tím, že o něčem neučíme (Margolis, 2002). Informální či nulové kurikulum považujeme za součást skrytého kurikula a nevěnujeme jim zde proto zvláštní pozornost. 
Biografický a narativní př́ístup skýtá možnost studovat skryté kurikulum perspektivou těch, kteř́i byli jeho přímými a každodenními aktéry. Tím, že jim aspekty skrytého kurikula zůstaly v paměti i po letech, kdy školu opustili, lze usuzovat na významnost těchto aspektů edukační reality. Proto pátráme po subjektivních zkušenostech studentů učitelství se školou, které odkazují ke skrytému kurikulu. Domníváme se, že tyto zkušenosti tvoří důležitý prostředek k utváření jejich profesní identity. Cestou k odhalení některých oblastí skrytého kurikula se stala narativní analýza příběhů studentů učitelství o jejich zkušenosti se školou.

\section{Narativ a jeho analýza $v$ pedagogice}

Narativ neboli vyprávění můžeme na nejobecnější úrovni popsat jako specifický proces verbální komunikace, ve kterém spolu interagují nejméně dva sociální aktéři: vypravěč a posluchač. Nicméně pro vznik narativní struktury nestačí, aby sdělované události byly řazeny za sebou, musí být i kauzálně propojené (Hájek, Havlík, \& Nekvapil, 2012, s. 202). Aby se to, co někdo popisuje, dalo nazvat narací, musí vyprávění obsahovat prvek zápletky. Zápletka vytváří $\mathrm{v}$ příběhu souvislosti, takže se $\mathrm{z}$ něj stává celistvý sled řady př́íhod (Ricoeur, 1985). Narativ se tedy od ostatních textových útvarů odlišuje tím, že je chronologický (Chatman, 2000).

Vzhledem k výzkumnému využití narativů je třeba se zamyslet nad vztahem prríběhu a reality. Hábl (2014) si klade otázku, zda příběh realitu odhaluje nebo ji utváří. Odpověd' shledává v tom, že se obojí nevylučuje. Příběh odhaluje uspořádání reality a také ovlivňuje realitu pomocí slov. Pro naše analýzy je podstatné zmínit, že příběh není objektivním odrazem reality. Jak uvádí Čermák (2002), př́běh je nositelem interpretace, mnohdy tacitní, neviditelné, je tudíž jak faktem, tak interpretací. Jedinec konstruuje minulé události a jednání v osobních narativních jednotkách, aby dal najevo určitou identitu a způsob i výsledek tvorby svého života. Čermák (2002) dále dodává, že příběh je dobrou metaforou nejenom pro obecné meditace o jedinci, ale i pro výzkum. Narativita je podle něj hlavním módem lidského vědění, ač věda tento fakt dosud zcela nevstřebala. Přesto se s narativem pojí řada problémů. Zejména je to problematika porozumění (srov. Gadamer \& Mik, 2010) a nespolehlivost. Nespolehlivost Kubíček (2007, s. 172) definuje jako funkční vědomé, účelové a záměrné překroucení či nedostatečné informování o příběhu, jeho událostech a postavách. Jedná se o vyprávěcí strategii, 
kterou Kubíček (2007) identifikuje na dvou rovinách: na rovině př́iběhu (nespolehlivý vypravěč) a na rovině vyprávění (nespolehlivé vyprávění). V literárněvedním kontextu závisí rozpoznání nespolehlivosti na schopnostech čtenáře, $v$ sociálněvědním kontextu pak na výzkumníkovi a př́padně i na čtenářích výzkumné zprávy, pokud jim to umožňuje kvalita prezentovaných dat. Sociální vědy i přes mnohá rizika našly v narativech „zdroj dat“ a způsob hledání porozumění sociální realitě.

Vlna narativních analýz vyvstala v sociálních vědách $\mathrm{v}$ posledních čtyřiceti letech (Rutten \& Soetaert, 2013). Také pedagogické vědy nezůstávají pozadu. Narativní biografie a narativní výzkum se zde využívá od přelomu let osmdesátých a devadesátých. Existují výzkumy kariéry učitele základní školy, kariéry učitelek, výjimečných učitelů, psaní příběhů učiteli, životní historie učitelek v důchodu, dekonstrukce obrazu učitelky jako matky či zkoumání autobiografických záznamů učitelů (Švaříček, 2009). V české pedagogické vědě k této metodologii přispěli naprríklad Gavora (2001), Lukas (2006) a Švaříček (2009).

Narativní analýzu kurikula odstartovali Connelly a Clandinin v polovině osmdesátých let. Conelly a Clandinin pracovali $s$ učiteli, kteří sdíleli př́íběhy, biografie, dopisy atd. Na základě této zkušenosti vznikla vlivná publikace Teachers as Curriculum Planners: Narratives of Experience (Connelly \& Clandinin, 1988), ve které autoři docházejí k nezastupitelnému významu zkušenosti učitele pro realizaci edukačního procesu a plánování kurikula. Jejich výzkum byl průkopnický ve své době také v tom, že na tvorbu kurikula bylo nahlíženo zejména skrze vzdělávací politiku. Connelly a Clandinin ale ukazují, že kurikulum je tvořeno spíše zkušenostmi učitelů než vzdělávací politikou a jejími dokumenty danými shora (Kitchen, Parker, \& Pushon, 2011, s. 62). Současné narativní př́ístupy k oblasti kurikula jsou poměrně bohaté a rozrůzněné, možná i proto, že sama oblast kurikula je velmi široká.

Přestože pedagogika vzala narativ v potaz jako součást vědeckého poznání i edukační praxe, není celá tato oblast bez problémů. Z metodologického hlediska je některým textům $v$ pedagogice vyčítáno, že se jedná o narativy bez analýzy. Čtenář v nich většinou nalezne význam, data jako př́iběhy jsou ale jen př́běhy, nejsou výzkumem (Fowler, 2006). Autoři často nespecifikují své metodologické přístupy. Př́íspívají k tomu možná i iniciátoři narativních př́ístupů $\mathrm{v}$ pedagogice Conelly a Clandinin, kteří považují práci s narativy spíše za způsob uvažování o kurikulu než za vědeckou metodu (Kitchen et al., 2011, s. 50). 
Narativní analýza je pro nás přesto zajímavým a užitečným prostředkem pro určité typy výzkumných problémů v pedagogice. Mezi tyto výzkumné problémy patří i skryté kurikulum, nebot' jak uvádí Hafferty a O’Donnell (2015), narativní analýzu lze považovat za okno do skrytého kurikula.

\section{Metodologie aneb jak zkoumat, co je skryté}

Zkoumání skrytého kurikula je metodologicky obtížné už z jeho podstaty, nebot' lépe se zkoumá to, co je zjevné (např. přímo pozorovatelné), než to, co je skryté. Skrytost však neznamená neodhalitelnost, ale spíše nezjevnost, protože relevantní školské fenomény nejsou prvoplánové, ale jsou víceméně překryté oficiálním diskursem (Kaščák, 2011, s. 31). Skryté kurikulum odkazuje k brýlím na očích zainteresovaných osob (Kaščák \& Filagová, 2007, s. 13). Paradox „Zjevení nezjevného“ částečně řeší Portelliho (1993, s. 347) teze, že „zkoumání skrytého kurikula není zaměřeno jen na to, co je skryté, ale mělo by směřovat k otázce kým a pro koho je to skryté“. To, co může být vědomě či nevědomě skryté pro učitele, může být naopak zjevné pro žáka. Právě žákovskou perspektivu jsme zvolili v této studii. S tím souvisí podoba sebraných dat, která nejsou objektivním obrazem reality, ale subjektivním vnímáním žáka. Tento charakter dat přitom nikterak nedegraduje jejich význam, protože $\mathrm{v}$ žákovské perspektivě tkví to, co si žáci ze školy odnáší (dosažené kurikulum).

Cílem výzkumu bylo zjistit, s jakými podobami skrytého kurikula se setkali studenti Pedagogické fakulty MU v průběhu svého primárního a sekundárního vzdělávání. Výzkumný vzorek tvořili studenti bakalářského studia různých kombinací oborů asistentství pro základní školy. Ve vzorku bylo celkem 88 studentů, kteří v podzimním semestru 2014 navštěvovali Seminář k teorii a metodice výchovy. Datový korpus tvoří seminární úkol z tohoto předmětu 4 . Úkolem bylo napsat vlastní příběh, který zachycuje negativní zkušenost se základní nebo střední školou. Zde je třeba zopakovat, že skryté kurikulum zahrnuje jak pozitivní, tak i negativní jevy. Zaměření na negativní jevy sloužilo k zacílení vyprávění a také ke generování příběhů, které obsahují určitou

\footnotetext{
Seminární úkol se skládal ze tří kroků. V prvním kroku studenti pouze deskriptivně popsali svůj př́iběh (ač někteří přistoupili částečně k reflektivnímu psaní). Proto jsou součástí datového korpusu také texty, které nemají strukturu narativu. V druhém kroku se studenti zamysleli nad svým př́během z pozice učitele a ve třetím kroku studenti srovnali perspektivu žáků a učitelů v konkrétní situaci a formulovali doporučení pro vlastní pedagogickou praxi. Pro účely analýzy bylo využito pouze 88 př́běhů z prvního kroku úkolu.
} 
kontroverzi. Byl za ním mimo jiné přepoklad, že negativní zkušenost odpovídá skrytému kurikulu v tom, že není ve škole vyvolávána záměrně - na rozdíl od pozitivní zkušenosti, která je záměrem formálního kurikula. Vycházeli jsme také z toho, že skryté kurikulum může být v konfliktu s formálním kurikulem a také s hodnotami studenta (Hafferty \& O'Donnell, 2015). Je však třeba zmínit, že rozdělení jevů na pozitivní a negativní je nepřesné, nebot' řada negativních zkušeností přinášela i pozitivní efekty a naopak. Mnoho vyprávění končilo tím, že „všechno špatné je pro něco dobré“. Zvolená metodologie také nedokáže zachytit všechny aspekty skrytého kurikula, a to zejména ty, které jsou spojeny s formálním kurikulem. K jejich zkoumání by bylo třeba zaměřit se na analýzu učebnic či školních vzdělávacích programů. V narativech je skryté kurikulum zkoumáno především skrze vyprávění o interakcích ve škole a o pravidlech školy.

Vzhledem k tomu, že narativy psali studenti druhého ročníku bakalářského studia, zachycují subjektivní zkušenosti z české základní a střední školy v období přibližně před 2 až 15 lety. Zaměření je širší proto, že nebylo cílem sebrat zkušenost vztahující se konkrétně k základnímu nebo střednímu vzdělávání, ale zkušenost, která je pro studenta z nějakého důvodu významná a tudíž mu utkvěla $v$ paměti. $V$ datovém korpusu jsou bohatě zastoupeny jak příběhy z primárního vzdělávání, tak i z nižšśho a vyššího sekundárního vzdělávání (ISCED 1 - ISCED 3).

Zvoleným analytickým přístupem byla narativní biografie (srov. Švaříček, 2009). Nejedná se přitom o životní příběh (life story) jako celek, ale o okamžiky ze školního prostředí, které respondenti chápou jako významné (srov. Makovská, 2011). Analýza dat probíhala induktivně. Skrze otevřené kódování byl text segmentován na dílčí jevy, které byly dále integrovány do vyšších celků a byly mezi nimi hledány vztahy (srov. Gavora, 2001). Anonymizováni byli nejen autoři, ale i všichni aktéři příběhů.

\section{$4 \quad$ Výsledky výzkumného šetření}

Nejen skryté kurikulum, ale i další jevy a procesy ve školní třídě jsou většinou spojeny s osobou učitele. Učitel je klíčovým aktérem vzdělávání ve škole. Výsledky výzkumu by se proto mohly vztahovat ke kategorii učitel. K podobnému zjištění dospěla také Makovská (2011) ve výzkumu moci v žákovských vyprávěních. Kategorii učitel proto záměrně opouštíme. Výsledky výzkumu prezentujeme ve dvou hlavních kapitolách, které odlišují skryté kurikulum 
dle kritéria hierarchičnosti pozic aktérů ve škole, mezi kterými se skryté kurikulum utváŕí. První kapitola zachycuje skryté kurikulum ve vztahu žáků a představitelů instituce školy. Je tedy hierarchické a nazýváme ho vertikálním skrytým kurikulem. Druhá kapitola popisuje skryté kurikulum vztažené k socializaci ve vrstevnické skupině ve škole, tedy především ve školní třídě, která je charakteristická nehierarchickými vztahy. Označujeme ho jako horizontální skryté kurikulum.

\subsection{Skryté kurikulum a instituce školy: vertikální skryté kurikulum}

Skryté kurikulum bývá často spojováno s hodnotami, normami a rituály ve škole. Hodnoty a normy obsažené ve skrytém kurikulu přitom mohou být v rozporu s hodnotami a normami v kurikulu formálním. Právě hodnoty a normy ve škole, které jsou do určité míry konfliktní ve vztahu k formálnímu kurikulu, některá vyprávění odhalila. Př́íklad hodnotového konfliktu formálního a skrytého kurikula uvedeme skrze prosociálnost, která byla obsahem několika studentských vyprávění. Ve formálním kurikulu je prosociálnost deklarovanou hodnotou stejně jako s ní související norma spolupráce. Avšak v podmínkách instituce školy jsou podoby prosociálního chování limitované. Někteří studenti popisovali příběhy, ve kterých byli za prosociální chování naopak potrestáni. Takový je prŕiběh Vlad'ky:

Zkrátka jsem pomáhala své kamarádce napsat domácí úkol. Profesorka na to prrišla a dala nám oběma za „5“. Moc jsem to nepochopila, vždyt' to byl domácí úkol a stejně tak jí mohl doma pomáhat někdo jiný a nepřišlo by se na to. Šok pro mě byl až to, když mi za to dala dvojku z chování a kamarádce ředitelskou důtku.

Nevíme v jakých podmínkách se zadání úkolu a potrestání obou aktérek odehrálo. Důležité je však vnímání trestu, které Vlad'ka popisuje jako šok. Trest tedy vnímala jako přiliš přísný a hlavně neadekvátní svému chování. Takový trest je pak spíše považován za nespravedlnost, než aby bylo nahlédnuto na to, proč by bylo vhodné na úkolu pracovat samostatně, jaký benefit by z toho kamarádka mohla mít. K výchovnému efektu situace by spíše přispělo její porozumění aktéry než pouze aplikace trestu. Pomoc a spolupráce zde neměla své místo, ani po letech však Vlad'ka neví proč.

Kromě hodnot a norem zahrnuje skryté kurikulum také rituály. Můžeme vymezit dva protichůdné rituály, a to rituály diktátorství a rituály demokracie. Vzhledem k zadání narativu převládají v datech rituály diktátorství, což však v žádném případě nekopíruje realitu školy. Rituály demokracie ve škole 
popisuje například výzkum Kratochvílové (2014). Ilustrovat zde tedy budeme jeden z rituálů diktátorství skrze metaforu učitele diktátora, kterou popsala Karla:

Předcházela ji velmi nelichotivá pověst. Jakmile se objevila na konci druhé chodby a my uslyšeli ten děsivý klapot jejích bot, celá třída utichla a čekala, co se bude dít dál. Když k nám paní Nováková došla, první, co udělala, vykřikla: „Jak si to představujete stát tady jako nějaké hloupé stádo! Je vidět, že blbost nechodí po horách, ale po první bé! Od přriště budete stát ve dvou řadách, a jakmile přijdu, pozdravíte!" Až teprve po tomto výstupu nás pustila do třídy, kde nám začala dlouze vysvětlovat, jak bude probíhat úvod každé naší hodiny: „Postavte se! Já pozdravím Good morning everybody! A vy odpovíte Good morning, Mrs. Nováková!“ Jen co jsme jako ovce odř́kali tento pozdrav a dosedli na svá místa, udeřila rukou do stolu a svým hrubým hlasem spustila: „U mě neexistuje demokracie! Budete poslouchat to, co já vám řeknu, a co řeknu, to také vždy platí, takže nechci slyšet žádné vaše názory! Ted' si vezměte sešit a pište!“

Učitelka dále dle narativního záznamu žákům nadiktovala pravidla, podle kterých se mají v hodinách angličtiny chovat. V jednání učitelky Novákové je jistá záměrnost. Pravděpodobně usiluje o nastolení kázně ve třídě, která je nezbytná pro vytvoření klimatu, ve kterém může probíhat učení (Lewis, 2008). Avšak v perspektivě žáků k nastolení kázně využívá rituály, které autoritu učitele posouvají $\mathrm{k}$ autoritářství. Žáci tak skrze tuto učitelku vnímají moc instituce, které jsou součástí.

Vyprávění zrdcadlila moc instituce školy, která významně utváří skryté kurikulum (srov. Kaščák, 2006). Definice moci jakožto možnosti či schopnosti ovlivňovat chování jiných (srov. McCroskey \& Richmond, 1983) ji v prostředí školy automaticky situuje „do rukou“ učitele (Makovská, 2011). Přestože učitel je často oním zprostředkujícím prvkem, v této kategorii popisujeme narativy, které nevypovídají o jednom konkrétním učiteli, ale mají tendenci odhalovat některé aspekty moci školy jako specifické instituce. Důležité je hned na začátku zmínit, že pokud si moc představíme jako škálu vnímaného vlivu žáky (od velmi silného po velmi slabý vliv), vyprávění zachycují obě strany spektra - tedy moc i bezmoc školy.

V narativech o moci školy se objevuje vykreslení školy jako instituce, která moc absolutně drží, kde žák je podřízen její libovůli a nemá právo se odvolat, i když vnímá represi této instituce jako nespravedlivou. Celkově v tomto př́istupu převažuje vymezení „my“ (žáci) a „oni“ (učitelé), kde žáci nemají právo na svůj hlas. Moc školy je pak percipována jako bezmoc žáka: 
Tenkrát jsme měli v čítance nějaký zajímavý text, který byl napsaný jen jednou větou a já si jako obvykle četla napřed. Byla jsem už skoro u konce, když mě učitelka vyvolala. Obrátila jsem stránku zpět, nebot' jsem věděla skoro přesně, kde jsme. Ona si to však vyložila tak, že nedávám pozor. Ani moje vysvětlování, ani slzy ji nepřesvědčily o opaku. Velmi se rozzlobila a nechala mě po škole celý článek opsat. Text obsahoval asi 400 slov, ale pro osmiletého žáka to byla práce minimálně na dvě hodiny. Když na to vzpomínám, opět se mi vybavují některá slova, bolest ruky od psaní a hlavně obrovská bezmoc. Nechápala jsem, proč mi učitelka nevěří a trestá mě tak přísně. (Dana)

Dana sama sebe charakterizuje jako vzornou žákyni, kterou vyučování bavilo, a v českém jazyce si texty četla napřed, protože ji zajímaly. Tím se však dostala do situace, kdy nedokázala okamžitě reagovat na pokyn učitelky a byla za to potrestána. $V$ př́bězích bezmoci je trest samozřejmě vnímán jako nespravedlivý. $V$ tomto typu prŕběhů se studenti $v$ důsledku své bezmoci cítí ve škole jako „občané druhé kategorie“. Škola je skutečně instituce se strukturální nerovností, která vyplývá i z jedné z nerovností ve společnosti - nerovnosti dětí a dospělých (Pratto et al., 2008). K naplnění této nerovnosti přispívá v edukační realitě pak i to, že pro žáky a učitele platí ve škole odlišná pravidla:

Učitelka vstala a chystala se $\mathrm{k}$ odchodu. $\mathrm{V}$ tom si ale všimla bahna, které sem bylo naší třídou zavlečeno. Rozkřikla se: „Kdo to sem tahá?! Všichni mi hned ukažte přezůvky!“ Nad hlavy se zvedly přezůvky. Bohužel jen jedny ze třiceti. „V̌̌ichni se hned padejte přezout, uklízečka to tady po vás nebude uklízet," pravila př́sným rozčíleným hlasem. „Tak to snad abyste šla s námi,“ odpověděla jí spolužačka, a pokynula hlavou na její kožené kozačky na vysokém podpatku. Učitelka zasupěla: „Co je to za drzost? Dej sem třídnici, at’ ti tam můžu napsat poznámku. Jak se jmenuješ?“ "Hlaváčková,“ odpověděla. „Já jen, když vám tak záleží na práci paní uklízečky, tak byste se taky mohla přezouvat.“ „Já se přezouvat nemusím, já jsem učitel,“ vykřrikla učitelka. „A jaký je teda rozdíl, jestli tu našlapu já, nebo vy?“ Učitelka právě dopsala poznámku. Stálo v ní: „Je drzá k učiteli.“” „Višš, proč se učitelé nemusí přezouvat? Protože učitelé jsou chytřejší než žáci!“" (Stanislav)

Tato středoškolská „historka“ vygenerovala argument, který se snaží (ne)logicky zdůvodnit nerovnost učitele a žáka ve školní hierarchii a s ní související odlišné normy v daných sociálních pozicích. Aktéři na pozici dominance se spíše chovají způsobem, který jim umožní udržet dominanci, třeba tím, že produkují vysvětlení, která ukazují hierachii jako zdůvodněnou. Oproti tomu členové podřízených skupin se častěji chovají způsobem, který normy konfrontuje a snaží se propagovat rovnost (Saguy, Tropp, \& Hawi, 2013). Proto mohou žáci normy zpochybňovat častěji než učitelé. 
Hierarchičnost pozic učitele a žáků však nemusí přispívat jen k úsměvným historkám. Může vyvolat i pocit, který si ze školy odnáší Světlana:

Na svou bývalou školu vzpomínám jako na instituci, která se ř́́dí vlastní logikou. Normálně myslící člověk tam nemá co pohledávat. Navíc odjakživa jsem nenáviděla takovýto druh bezmoci. Celé své tamnější studium jsem byla ten studentík, nicka, která se nesmí ohradit ani v př́ípadě, že je to opravdu na místě.

Světlana vztahuje svůj pocit bezmoci k instituci školy celkově a vytváří si tak specifický obraz školy i žáků v ní. I toto vnímání instituce můžeme chápat jako součást jejího skrytého kurikula. Typické je zejména v kritickopedagogických směrech, které ukazují žáky jako relativně bezmocné aktéry, které škola využivá k reprodukci mocenských vztahů ve společnosti. Záznam Světlany však za hranici školy nejde a nezachycuje význam této „submisivity“ pro další sociální role. K diskusi o moci školy přidáme ještě jeden prŕiběh, který je specifický vnímáním synergie moci školy a rodiny. Jarka v něm sama sebe vnímá jako obět' komplotu učitelky a matky, tedy dvou aktérů v nadřazené sociální pozici. Ve svém příběhu popisuje, jak jí učitelka ZŠ slíbila, že si může napsat přijímací zkoušky na víceleté gymnázium jen zkušebně a že ji nikdo k přestupu nutit nebude. Jakmile ale zkoušky úspěšně složila, zjistila, že její matka s učitelkou se dohodly za jejími zády a přihlášku podaly. Přinutily ji opustit oblíbenou základní školu, načež se Jarka v průběhu celého studia na víceletém gymnáziu cítila neštastná. Př́iběh nese pocit pošramocení důvěry ke dvěma významným aktérům sociální relity - k rodiči a učiteli. Je zřejmé, že motivy učitelky i matky měly „dobré důvody“, ale efekt, kterého tím dosáhly, se obrátil proti nim. Matce i učitelce bylo připisováno vše negativní v nové škole, veškerou odpovědnost tímto jejich krokem žákyně přenesla na ně. Př́́běh ukazuje křehkost role rodiče a učitele ve skrytém kurikulu skrze zneužití důvěry z mocenské pozice matky a učitelky.

Žáci ve škole však nejsou jen pasivními objekty moci. Mnohdy ve škole revoltují, chovají se rezistentně. Součástí konceptu moci je rezistence, nebot' moc vždy produkuje nějakou podobu rezistence (Danaher, Schirato, \& Webb, 2000). Rezistenci lze vymezit jako opoziční akt k něčemu, s čím jedinec nebo skupina nesouhlasí (Sannino, 2010) a můžeme ji chápat jako soutěž o moc. Zaměříme se tedy na aspekty skrytého kurikula, ve kterých žáci projevili nesouhlas s učitelem a snažili se dosáhnout vlastního záměru. 
Studenti popisovali množství příběhů, ve kterých byla ústředním tématem nespravedlnost, která se ve škole stala. Tato nespravedlnost může být vztažena k nim samotným, ke spolužákům, ale i k učitelům. Z hlediska skrytého kurikula je zajímavé podívat se na to, jak se $\mathrm{k}$ této nespravedlnosti studenti ve svých vyprávěních postavili a co si z ní odnesli. Část př́běhů obsahuje situace, kdy se studenti ozvali a za svá práva bojovali. Klára popisuje případ ztraceného testu a to, že odmítla test psát znovu:

Bylo mi v tu chvíli do breku, když jsem tam stála, ale chtěla jsem si udržet kamennou tvář a řekla jsem jí, že jsem test napsala i odevzdala, a tak se dalšího testu mimo vyučování účastnit nebudu. Ona byla velmi překvapená, ale asi v duchu pochopila, že si opravdu nevymýšlím.

Tyto příběhy rezistence, ve kterých žáci dokáží prosadit svá práva, kontrují vnímání absolutní moci instituce školy, která žákům hlas nedává. Kromě těchto případů, ve kterých žáci „dosáhli svého“, se v datovém korpusu vyskytují př́iběhy, kde to, že se žáci ozvali, nemělo požadovaný efekt, nebo dokonce vedlo $\mathrm{k}$ jejich další stigmatizaci či perzekuci. Žáci přitom nebojovali ve škole jen za sebe, ale i za druhé. Př́běh Kamily obsahuje takové volání po spravedlnosti, které $\mathrm{v}$ dané situaci subjektivně postrádala:

Dvěma z mých spolužáků dokonce hrozila nedostatečná a tak jim náš pan učitel nabídl přezkoušení. Kuriózní a zásadní věcí v tomto příběhu je, že oba mí spolužáci měli př́jmení Novotný. Jeden se jmenoval David - celkem oblíbený, veselý, takový třídní vtipálek; druhý se jmenoval Petr - do kolektivu nikdy moc nezapadl, možná proto, že jeho tatínek byl zbohatlík a my měli pocit, že na nás kouká skrz prsty, jako bychom mu nestáli ani za pozdrav. Nadešel den $D$ a oba hoši dostali u tabule tři př́klady. David zvládl vypočítat první a u druhých dvou alespoň nějak začal. Zato Petr celou dobu zápasil s prvním př́kladem a kloudného výsledku se nedobral. Usilovné přemýšlení mých spolužáků přerušilo zvonění, tak nám matikář sdělil, že výsledky oznámí na zítřejší hodině.

Když jsem v úterý ráno viděla na chodbě pana Novotného (otce Petra), nevěnovala jsem tomu př́lišnou pozornost. Co ovšem ve škole pan Novotný dělal, mi došlo při hodině matematiky. Po velké přestávce nakráčel matematikář důležitě do třídy s oznámením výsledných známek: „Novotný Petr - čtyři, Novotný David - 5." Tř́́dou to zahučelo. Vzhledem k tomu, že měli oba studenti stejné př́íjmení, rychlým uvažováním jsem došla k závěru, že se pan učitel spletl ve jménu, a tak jsem neváhala se přihlásit a tuto skutečnost mu říct. Jeho reakce mě opravdu překvapila: „Mlč Boháčková, nebo si tě vyzkouším taky“. A najednou mi došlo, co dělal pan Novotný u nás ve škole. Nejspíš měl v úmyslu dát škole velkorysý 
sponzorský dar, zaplatit vybavení učeben nebo něco podobného. Hlavně to muselo vypadat nenápadně, aby se tomu nedalo říkat úplatek. Po další tři roky na gymnáziu jsem měla s dotyčným učitelem velké problémy. Kdybych věděla, co mě čeká, možná bych si to rozmyslela, ale možná taky ne. Takže tři roky mučení v matematice jsem si vysloužila jen za to, že jsem chtěla spravedlnost. Je zvláštní, jaké zážitky a zkušenosti nám dává škola, instituce, která vychovává budoucí generace.

Kamila se dostala „bojem za práva“ druhého do obtížné pozice, která jí dle jejího mínění zkomplikovala další tři roky života v matematice. Není si jistá, zda by se rozhodla stejně, kdyby znala následky svého rozhodnutí předem. Pro ni samotnou je to téma k sebereflexi - být či nebýt hrdinou? Důležité však je, že odkrývá dimenzi skrytého kurikula ve škole. Školu vnímá jako instituci, která má „vychovávat“. Zde však nesla v dimenzi skrytého kurikula legitimizaci korupce. Kamila vystoupila rezistentě pouze jednorázově. V datovém korpusu jsou i př́iběhy, které zahrnují dlouhodobou rezistenci, nejčastěji v podobě „souboje“ žáka s učitelem. Žáci, kteří „vytáhli“ do individuálního boje za svá percipovaná práva, si z tohoto procesu odnáší intenzivní zážitek. Zcela nezáměrně prošli ve škole procesem, ve kterém otestovali sami sebe.

Strukturální nerovnost je přirozenou součástí instituce školy i společnosti. Žáci se budou i v budoucnu pohybovat v prostředích strukturální nerovnosti - v zaměstnání (ve škole jako učitelé), v rodině jako rodiče atd. Učení se o těchto prostředích skrze život $v$ těchto prostředích tak můžeme chápat jako významnou součást skrytého kurikula

Jak již zaznělo na začátku, nejsou to jen vyprávění o moci školy, ale i o její bezmoci, která dokreslují, jak žáci vnímali a dodnes vnímají tuto instituci. Karta se zde obrací a hierarchická struktura se stává naopak slabou, ovládanou těmi, kteří jí mají být podřízeni:

Mým největším přáním, když jsem chodila na základní školu, bylo zavedení tělesných trestů. „Zábava“ o přestávkách vždycky sestávala z ničení školního majetku, ničení věcí ostataních a házení popřípadě ždímání mokré houby na sebe navzájem a každého dalšího, koho se jim podařilo chytit (to hlavně v zimě). A na tohle měli celých deset minut přestávky, o svačinové dokonce dvacet. Ze strany učitelů nikdy nedošlo k ničemu horšímu, než poznámce, což bylo samozřejmě naprosto neúčinné. (Iva)

Zatímco část vyprávění zobrazuje školu jako instituci, která disponuje absolutní mocí, kterou může snadno zneužít, jiná vyprávění vypovídají o opaku, 
o škole jako instituci bezmocné, která nedisponuje vhodnými a adekvátními prostředky $\mathrm{k}$ tomu, aby mohla zajistit sociální fungování jejích aktérů, nebo dokonce naplňovat didaktické cíle. Nedostatečné mocenské prostředky jsou shledávány zejména v oblasti kázně. Možná proto se studentka Iva uchýlila ke „snu o fyzických trestech“, které by bezmocnou školu učinily mocnou.

Důležitá pro učitelské vzdělávání a uvažování o učitelské roli je nejen percipovaná bezmoc školy k možnostem disciplinovat žáky, ale i percipovaná bezmoc konkrétních učitelů. Tématu bezmoci učitele se věnovala Nad'a. Popsala, jak se část žáků postavila proti učitelce matematiky, která byla podle Nadi spravedlivá a dokázala naučit, ale měla na žáky vysoké požadavky. Píše, že jedna třetina tř́dy v alianci s rodiči a na základě lži „překřičela“ pasivitu dvou třetin spolužáků. $\mathrm{V}$ dimenzi skrytého kurikula se zde pro studentku, která příběh napsala, skrývá ponaučení o tom, že výkon role učitele je determinován řadou faktorů, nejen jeho kvalitou.

Popsali jsme některé aspekty moci školy. Obsahem skrytého kurikula je zde moc či bezmoc jedné z prvních formálních institucí, se kterou se žáci v životě setkají. Pro budoucí učitele má však uvažování o moci této instituce specifický význam, nebot' škola bude rámovat jejich budoucí profesní uplatnění.

Škola nese vertikání skryté kurikulum, tedy kurikulum, které se vztahuje $\mathrm{k}$ aktérům na odlišných sociálních pozicích. $\mathrm{V}$ průběhu socializace zde žáci zažívají pocity moci i bezmoci instituce školy, subjektivně vnímají spravedlnost a nespravedlnost, učí se o hierarchických vztazích, o konformitě i nonkonformitě, zkoušejí si rezistenci a její následky a především se učí o sobě samých. Tyto zkušenosti spojujeme s vertikálním skrytým kurikulem. Druhou část skládačky skrytého kurikula v naší analýze pak tvoří jeho nehierarchická podoba, tedy horizontální skryté kurikulum.

\subsection{Skryté kurikulum a školní třída: horizontální skryté kurikulum}

Druhou dimenzi skrytého kurikula popíšeme ve vztahu ke školní tř́dě. Kolektiv školní třídy tvoří jedno $\mathrm{z}$ významných socializačních prostředí, nesoucí hodnoty a normy, které mohou být odlišné od formálního kurikula a požadavků školy. ${ }^{5} \mathrm{~V}$ datech tento rozpor mnohokrát vyvstal a korpus tak obsahuje řadu př́běhů, které v sobě nesou dilema „být s učitelem“, nebo „být se spolužáky“? „Být s učitelem“ znamená naplňovat cíle školy, chtít se učit

\footnotetext{
Dalšími socializačními prostředími, která mohou být v rozporu s formálním kurikulem a požadavky školy, jsou např́klad rodina, vrstevnická skupina, masmédia. Na jejich analýzu se však v tomto textu nezaměřujeme.
} 
a zajímat se o různé předměty. Oproti tomu „být se spolužáky“ v tomto dilematu znamená rozporovat normy školy a hlavně nesdílet cíle s učitelem, tj. nechodit do školy proto, abychom se něco naučili. Toto dilema řešili zejména žáci, kteří v některém předmětu vynikali. Výstižně toto dilema popisuje Katka skrze metaforu „tajné lásky“: „Kromě zeměpisu mě bavily v podstatě všechny předměty. Nejvíce jsem se ale těšila na dějepis. Byla to taková moje tajná láska. Tajná proto, že se mezi ostatními ,nenosilo' mít rád učení.“

Skryté kurikulum je tedy utvářeno mimo jiné žákovským kolektivem, tím, jaké významy žáci připisují předmětům a cílům školy vůbec. V některých př́ípadech je toto kurikulum vymezením se vưči kurikulu formálnímu. Žáci, kteří sdílejí cíle formálního kurikula, toto musejí v některých případech utajovat, aby byly konformní s třídním kolektivem. Nejen didaktická oblast nese takové dilema. Jestli má „být se svým spolužákem“, nebo naplnit očekávanou normu chování, řešil Petr v jednom z míst školy, kde lze dle Hemmingsové (2000) skryté kurikulum dobře zkoumat, a to jsou chodby školy. O přestávkách je totiž čas tráven v režii žáků, učitelé zasahují, jen když se situace vyhrotí. Přestávky dávají lekce skrytého kurikula a nejsou to lekce krátké, přestávky tvoří každodenně studentskou hodinu (Hemmings, 2000). Petr napsal:

Jak už to tak o přestávkách bývá, potloukali jsme po chodbách. Šli jsme jen já s jedním spolužákem, když v tom můj spolužák našel na zemi telefon. Hned jej zvedl, ale místo toho, aby jej napadlo ho vrátit, tak vyrukoval s tím, že si telefon nechá a určitě na to nikdo nepřijde a všechno bude v pohodě. Přes mé naléhání, že je to krádež a telefon by měl vrátit, zareagoval tak, že vytáhl SIMkartu a telefon strčil do kapsy. Na jednu stranu bych byl rád, aby se na tu krádež přišlo, ale udavač jsem být nechtěl, protože jediný, kdo o tom věděl, jsem byl já. Takže jsem se rozhodl doufat, že telefon bud' vrátí, nebo ho u něj nějakým způsobem najdou. Opravdu jsem v tu chvíli nevěděl, co dělat, abych se zachoval podle svého nejlepšího svědomí.

Zkoušce v dimenzi skrytého kurikula byl Petr podroben, když se měl rozhodnout, zda bude kamarádem, nebo spravedlivým člověkem, což však ve vztahu ke spolužákovi znamená být udavačem. Tyto role vnímal jako konfliktní. Jeho příběh je lekcí etické výchovy skrze skryté kurikulum. Taková lekce mưže být intezivnější než řešení fiktivních morálních dilemat v rámci formálního kurikula. Je totiž skutečná.

Kromě morálních dilemat je další významnou dimenzí skrytého kurikula ve vztahu ke trrídnímu kolektivu utváření a vyjednávání identity žákủ. Žáci se 
učí, kdo je insiderem a kdo outsiderem. Právě př́iběhy outsiderů dokreslují dimenzi školy, která přestože není žádoucí, je do jisté míry nevyhnutelná. Přináší zkušenosti se sociometrickým statusem, které mohou žáci percipovat u sebe či u druhých.

Jednou z identit utvářených ve škole právě v oblasti skrytého kurikula je identita genderová. Mnohé výzkumy hovoří o genderu v interakci učitele a žáků (srov. Jarkovská, 2013; Simonová \& Matějů, 2013). Genderová identita se však rozvíjí i v žákovském kolektivu. Mezi žáky dochází k přijetí nebo k odmítnutí očekávané genderové role. Preskripci své genderové role $\mathrm{v}$ žákovském kolektivu odmítala Alena, čímž se dostala do pozice outsidera ve tř́dě: „Nikdy jsem si s nimi moc nerozuměla, jelikož mě zajímaly i jiné věci, než panenky, lesky na rty nebo růžové šaty..."

Alena popisuje své začlenění do dívčího kolektivu, ve kterém se stává z důvodu svých zájmů neodpovídajících genderovým stereotypům outsiderem. Příběh Aleny patří do skupiny příběhů, $v$ nichž své pozice utvářejí převážně sami žáci. Ve škole jsou ale samozřejmě i situace, kde do struktury vztahů ve třídě intervenuje učitel. Přestože se jedná o intervenci učitele ve vztahu ke kolektivu, popisujeme tyto př́pady v horizontálním skrytém kurikulu, nebot' se týkají vztahu mezi žáky navzájem. Učitel může žáka na okraji skupiny podpořit, nebo naopak prohloubit propast mezi žákem a jeho spolužáky. Takto vnímal intervenci učitele Honza:

Po dlouhém a neelegantním kličkování úzkými uličkami blokovanými nespočtem poházených batohů jsem tedy sebral trrídní knihu a odebral se po poněkud bezpečnější cestě ke dveřím, na které jsem ovšem zakopl a lehce se hlavou udeřil o skříńku s televizí a videem. Sám jsem si z toho nic nedělal, ale po několika krocích jsem zaregistroval hihňání a tlumený smích, který mě donutil se otočit a prozkoumat onu vtipnou událost, která tak efektivně rozesmála celou tř́́du. „Co je?!“ zeptal jsem se davu, ale teprve když má slova dozněla, jsem si všiml paní učitelky, která na adresu mé „neschopnosti“ dělala dosti nevybíravá a ne přímo lichotivá gesta. Následné ostřelování slovy všech délek, kalibrů i hlasitosti mne efektivně vyhnalo ze třídy a, poprvé $\mathrm{v}$ mém životě, donutilo zvažovat variantu záškoláctví, jelikož vrátit se znovu do té místnosti bylo to poslední, co jsem chtěl.

Učitel tedy může ovlivnit žákovské vztahy i tím, že se přidá na stranu většiny žáků. $\mathrm{V}$ důsledku toho se může dále rozvíjet strategie žákovského kolektivu zaměřená proti outsiderovi. Jinou variantou intervence učitele je pak to, že učitel do žákovských vztahů neintervenuje. Kristýna popisuje neintervenci učitele do interakcí žáků v hodinách hudební výchovy: 
Při každé hodině jsem musela snášet jejich posměch... Do této situace nezasáhla ani vyučující hudební výchovy, která nikdy mé spolužáky žádným způsobem nenapomenula a i přes mou neochotu mě nutila účastnit se pěvecké soutěže.

Kristýna by uvítala intervenci učitele, která by umírnila posměch spolužáků. Ne každá intervence učitele či pracovníka školy do vrstevnických vztahů je však vnímána žáky jako vhodná. $V$ příbězích se objevila např́klad situace, ve které školní psycholožka obvinila třídu ze šikany spolužáka. V perspektivě autorky příběhu, která byla incidentům přítomna, se však jednalo jen o poštuchování, u kterého se bavily obě strany. Jako předsedkyni třídy jí pak byla připsána odpovědnost, kterou však subjektivně nevnímala. Tato situace přinesla nový pohled na vrstevnické vztahy a můžeme o ní uvažovat jako o součásti skrytého kurikula ve vztahu ke školní třídě.

Školní třída je prostředím utvářejícím hodnoty a normy v souladu či v rozporu s hodnotami a normami formálního kurikula. Je to také prostředí dynamické, které může žáky původně naladěné na cíle školy vyjádřené ve formálním kurikulu strhnout: „Během roku přestala poslouchat většina žáků. I moje spolusedící premiantka už tolik neposlouchala a při testu také opisovala. Dav prostě strhnul ostatní." (Věra). Skryté kurikulum žákovské skupiny rozporující cíle školy podle této výpovědi postupně převážilo v kolektivu a ovlivnilo i žáky původně nastavené na pravidla školy. Skryté kurikulum žákovské skupiny je tak něčím, co se neustále utváří.

At' skryté kurikulum tř́ídy působí proti formálnímu kurikulu, nebo v souladu s ním, je tř́ída důležité sociální prostředí, ve kterém dochází k informálnímu učení, a tím se v ní otevírá specifická oblast skrytého kurikula - horizontální skryté kurikulum.

\section{Diskuse a závěr}

Zabývali jsme se skrytým kurikulem skrze žákovskou perspektivu zachycenou v př́bězích o škole. Na základě narativní analýzy jsme popsali skryté kurikulum, které se utváří mezi aktéry na různých sociálních pozicích ve škole (vertikální), a to, které se rozvíjí v žákovském kolektivu (horizontální). I přes popsané negativní zkušenosti žáků chápeme skryté kurikulum jako prostředek sociální adaptace, bez které by měl žák problémy fungovat v širší společnosti (Kaščák \& Filagová, 2007, s. 149). Zkušenost se skrytým kurikulem je tedy významná pro všechny žáky, avšak pro studenty učitelství se může jevit jako kruciální. Vývoj profesní identity učitele je totiž ovlivňován 
mimo jiné představami o vyučování, které jsou spojeny s vlastními zkušenostmi v roli žáka a také obrazem učitelů, se kterými se studenti učitelství během své školní docházky setkali (Chong \& Low, 2009). Pravdová (2014) na základě výzkumu profesního sebepojetí studentů učitelství uvádí, že zkušenosti získané v roli žáka základní či střední školy jsou pro proces utváření profesního sebepojetí klíčové. Zatímco Pravdová zachycuje identifikaci žáka $\mathrm{s}$ učitelem, v našem výzkumu je tomu spíše naopak. Přestože žáci zažili problémové a konfliktní situace ve škole, zvolili si později učitelské vzdělávání. Domníváme se, že i tyto zkušenosti jsou pro ně velmi cenné a lze je dále vytěžit $\mathrm{v}$ profesní přípravě. $\mathrm{V}$ prvním kroku práce s narativy došlo ke zplnomocnění studentů k tomu, aby kritizovali instituci, jejímiž budou jednou představiteli. Sami se pak mnohdy definovali v opozici k učitelům ze svých příběhů a svoji profesní volbu zdůvodňovali tímto vymezením se vůči nim. Žádný příběh ale není černobílý a převyprávění př́iběhů z role učitele pak některým studentům otevřelo perspektivy, o kterých doposud neuvažovali. Vlastní příběh se stal přemostěním z role žáka do role učitele na základě subjektivně významné zkušenosti. Práce s narativy přispívá ke konfrontování vnímání situace různými aktéry sociální reality (Rutten \& Soetaert, 2013) a rozvíjí reflektivní myšlení. Psaní vlastních př́iběhů a jejich reflexe je tak specifickým modem učení.

Studenti skrze narativy o skrytém kurikulu zexplicitnili část svého „osobního kurikula", které je součástí jejich vědění a budoucích představ o učitelské profesi (Kitchen et al., 2011, s. 5). Conelly a Clandinin (1988) tvrdí, že tato osobní zkušenost determinuje plánování a výkon formálního kurikula. Dospívají proto $\mathrm{k}$ tomu, že u budoucích učitelů je nutností studovat sama sebe. I k tomu může zkoumání skrytého kurikula přispět.

\section{Literatura}

Ahwee, S., Chiappone, L., Cuevas, P., Galloway, F., Hart, J., Lones, J., ... Tate, B. (2004). The hidden and null curriculums: An experiment in collective educational biography. Educational Studies, 35(1), 25-43.

Aronowitz, S., \& Giroux, H. (2003). Education under siege: The conservative, liberal and radical debate over schooling. London: Routledge.

Bomba, L. (2013). Skryté kurikulum vo svetle metodologického holizmu a metodologického individualizmu. Pedagogická orientace, 23(1), 27-47.

Bulle, N. (2008). Sociology and education: Issues in sociology of education. Bern: Peter Lang.

Çobanoğlu, R. (2014). The visible side of the hidden curriculum in schools. Elementary Education Online, 13(3), 776-786. 
Connelly, F. M., \& Clandinin, D. J. (1988). Teachers as curriculum planners: Narratives of experience. Toronto: OISE Press.

Cotton, D., Winter, J., \& Bailey, I. (2013). Researching the hidden curriculum: Intentional and unintended messages. Journal of Geography in Higher Education, 37(2), 192-203.

Čermák, I. (2002). Myslet narativně (kvalitativní výzkum „on the road“). In I. Čermák \& I. Miovský (Eds.), Sborník z konference Kvalitativní výzkum ve vědách o člověku na prahu třetího tisíciletí (s. 11-25). Brno: Psychologický ústav AV ČR.

Danaher, G., Schirato, T., \& Webb, J. (2000). Understanding Foucault. London: Sage.

Dar, Y. (1995). Kibbutz education: A sociological account. Journal of Moral Education, 24(3), 225-244.

Fowler, L. C. (2006). A curriculum of difficulty: Narrative research in education and the practice. New York: Peter Lang.

Fryer-Edwards, K. (2002). Addressing the hidden curriculum in scientific research. The American Journal of Bioethics, 2(4), 58-59.

Gadamer, H. G., \& Mik, D. (2010). Pravda a metoda I: nárys filosofické hermeneutiky. Praha: Triáda.

Gavora, P. (2001). Výskum životného príbehu: Učitel'ka Adamová. Pedagogika, 51(3), 352-368.

Hábl, J. (2014). Učit (se) př́během: Komenského Labyrint a didaktické možnosti narativní alegorie. Brno: Host.

Hafferty, F. W., \& O'Donnell, J. F. (Eds.). (2015). The hidden curriculum in health professional education. Hanover: Dartmouth College Press.

Hájek, M., Havlík, M., \& Nekvapil, J. (2012). Narativní analýza v sociologickém výzkumu: př́ístupy a jednotící rámec. Czech Sociological Review, 48(2), 199-223.

Hargreaves, A. (1982). Resistance and relative autonomy theories: Problems of distortion and incoherence in recent Marxist analyses of education. British Journal of Sociology of Education, 3(2), 108-126.

Hemmings, A. (2000). The "hidden" corridor curriculum. The High School Journal, 83(2), 1-10.

Chatman, S. (2000). Dohodnuté termíny: rétorika narativu ve fikci a filmu. Olomouc: UP.

Chong, S., \& Low, E. L. (2009). Why I want to teach and how I feel about teaching - formation of teacher identity from pre-service to the beginning teacher phase. Educational Research for Policy and Practice, 8(1), 59-72.

Janík, T., Maňák, J., Knecht, P., \& Němec, J. (2010). Proměny kurikula současné české školy: vize a realita. Orbis scholae, 4(3), 9-27.

Jarkovská, L. (2013). Gender před tabulí: etnografický výzkum genderové reprodukce $v$ každodennosti školní třídy. Praha: Slon.

Jirásek, I. (2009). Skryté kurikulum: prostor nejen pro zážitkovou pedagogiku. e-Pedagogium, 9(3), 50-59.

Kaščák, O. (2006). Moc školy: o formatívnej sile organizácie. Trnava: Typi Universitatis Tyrnaviensis.

Kaščák, O. (2011). Rituály a skryté kurikulum alebo Kam v pedagogike zaradit’ rituálne štúdie? Teoretická (a biografická) rekonštrukcia. Studia paedagogica, 14(2), 29-40.

Kaščák, O., \& Filagová, M. (2007). Javisko a zákulisie školy. O materskej škole a skrytom kurikule. Trnava: Typi Universitatis Tyrnaviensis.

Kincheloe, J. L., \& Steinberg, S. R. (1997). Changing multiculturalism. Philadelphia: Open University. 
Kitchen, J., Parker, D. C., \& Pushon, D. (Eds.). (2011). Narrative inquiries into curriculum-making in teacher education. Bingley: Emerald.

Kratochvílová, J. (2014). Rituály v životě jedné školy. Komenský, 139(1), 19-25.

Kubíček, T. (2007). Vypravěč: kategorie narativní analýzy. Brno: Host.

Lewis, R. (2008). The developmental management approach to classroom behaviour: Responding to individual needs. Camberwell: ACER Press.

Lovat, T., Toomey, R., \& Clement, N. (Eds.). (2010). International research handbook on values education and student wellbeing. Dordrecht: Springer.

Lukas J. (2006). Životní př́iběhy učitelů - od kvalitativního ke smíšenému výzkumnému designu. In M. Kocurová (Ed.), Současné metodologické př́stupy a strategie pedagogického výzkumu. Sborník anotací 14. konference ČAPV (s. 36-36). Plzeň: Západočeská univerzita v Plzni.

Makovská, Z. (2011). Pojetí moci v žákovských vyprávěních. Studia paedagogica, 15(2), 141-152. Maňák, J. (2007). Modelování kurikula. Orbis scholae, 2(1), 40-53.

Margolis, E. (Ed.). (2002). The hidden curriculum in higher education. London: Routledge.

McCroskey, J. C., \& Richmond, V. P. (1983). Power in the classroom I: Teacher and student perceptions. Communication Education, 32(2), 175-218.

McLaren, P. (1998). Life in schools. Reading: Longman.

Ozolins, I., Hall, H., \& Peterson, R. (2008). The student voice: Recognising the hidden and informal curriculum in medicine. Medical Teacher, 30(6), 606-611.

Portelli, J.P. (1993). Exposing the hidden curriculum.JournalofCurriculum Studies, 25(4),343-358.

Pratto, F., Pearson, A. R., Lee, I. C., \& Saguy, T. (2008). Power dynamics in an experimental game. Social Justice Research, 21(3), 377-407.

Pravdová, B. (2014). Já jako učitel: profesní sebepojetí studenta učitelství. Brno: MU.

Ricoeur, P. (1985). Time and narrative (Vol. 2). Chicago: University of Chicago Press.

Rutten, K., \& Soetaert, R. (2013). Narrative and rhetorical approaches to problems of education: Jerome Bruner and Kenneth Burke revisited. Studies in Philosophy and Education, 32(4), 327-343.

Saguy, T., Tropp, L. R., \& Hawi, D. R. (2013). The role of group power in intergroup contact. In G. Hodson \& M. Hewstone (Eds.), Advances in intergroup contact (s. 113-132). New York: Psychology Press.

Sannino, A. (2010). Teachers' talk of experiencing: Conflict, resistance and agency. Teaching and Teacher Education, 26(4), 838-844.

Simonová, N., \& Matějů, P. (2013). Koho znevýhodňuje škola: chlapce, nebo dívky? Rozdíly v dovednostech, školních výsledcích a vzdělanostních aspiracích dívek a chlapců devátých tříd základních škol. Orbis scholae, 7(3) 107-138.

Švaříček, R. (2008). Úhly pohledu. Recenze na knihu Javisko a zákulisie školy. O materskej škole a skrytom kurikulu. Studia paedagogica, 13(1), 169-173.

Švaříček, R. (2009). Narativní a sociální konstrukce profesní identity učitele experta. (Disertační práce). Brno: MU

Valenta, J. (2009). Kurikulum životních dovedností (témata a problémy). Pedagogika, 59(2), 198-214.

Willis, P. E. (1977). Learning to labor: How working class kids get working class jobs. New York: Columbia University Press. 


\title{
Autorka
}

Mgr. Kateřina Lojdová, Ph.D., Masarykova univerzita, Pedagogická fakulta, Katedra pedagogiky, Poříčí 31, 60300 Brno, e-mail: lojdova@ped.muni.cz

\section{Hidden curriculum, lived stories. Student teachers' narratives about school}

\begin{abstract}
This empirical study focuses on hidden curriculum in narratives of 88 student teachers about their previous school experience. The narrative analysis showed two types of hidden curriculum: vertical and horizontal. Presented typology is based on classification of social position among actors sharing hidden curriculum. Vertical hidden curriculum is connected with actors on different social positions in school, e. g. teachers and pupils. It consists of value conflict between pupils and school, rituals to reproduce values in school, power of school, pupils resistance, powerlessness of school. Horizontal hidden curriculum refers to actors in the same social position, i. e. pupils. It is connected with values as well, but these values are shared among pupils. Pupils identity is negotiated within horizontal hidden curriculum. This part also describes teacher's intervention in relationship structure of the classroom. Towards the end of the paper we discuss the importance of these experiences for future teachers.
\end{abstract}

Keywords: biography, hidden curriculum, narrative analysis, student teachers

Prudký, L. (2015). Rozvoj osobnosti vysokoškoláků jako součást kvality výuky (Témata a otázky k pojetí vysokoškolského studia jako učení se svoboděj. Brno: CDK.

Publikace se zabývá dosud málo respektovanou problematikou - působením vysokých škol jako výchovných institucí. Součástí studia na vysoké škole je utváření osobnosti každého studenta. Utváření osobnosti je spojeno především s procesem interiorizace hodnot. Jde o to, jaké hodnoty vysoké školy a vzdělávání na nich studentům nabízí. Mělo by jít o hodnoty žádoucí. Publikace hodnotí aktivity spojené s učením se svobodě jako základ dobrého působení vysokých škol na rozvoj osobnosti jejich studentů. Rodíme se s dispozicí ke svobodě, bez učení se svobodě tyto dispozice ale neumíme uplatňovat. Do jaké míry se vysokým školám daří, aby se jejich studenti během studia současně učili svobodě, je atributem míry kvality těchto škol a studia na nich. Tuto dimenzi kvality vysokoškolského vzdělávání dosud téměř vůbec nebereme v úvahu. 